\title{
The Effectiveness of Video Blog (VLOG) on Students' Speaking Skill
}

\author{
Riza Weganofa*, Ilmatul Khoiro \\ English Education Study Program \\ Universitas PGRI Kanjuruhan Malang \\ Malang, Indonesia \\ *rizaweganofa@unikama.ac.id
}

\begin{abstract}
As speaking requires the students to perform orally, this skill is considered difficult by some students. This study aims at investigating the effectiveness of Video Blog (Vlog) on students' speaking skill. It used pretest-posttest control group research design. It was conducted at SMKS PGRI Pakisaji. The sample of the study were the ten grades of AKL students as the experiment class and the ten grades of OTKP students as the control class. The total of both classes were 36 students. The researcher used a speaking test as the instrument to collect the data. The result of post-test indicated that the students in experimental class has higher score than the control class on their speaking test. The result of statistical analysis reported that there was a significant difference scores between experimental and control class. According to the finding of this study, it could be concluded that vlog can be one of the best new media in teaching speaking and it is recommended to applied on teaching speaking process, because the students who are taught by using Vlog have better achievement in speaking skill. Therefore, Vlog is an effective media in teaching speaking skill.
\end{abstract}

Keywords-Video Blog (Vlog), speaking, video recording, effectiveness, 21st century education

\section{INTRODUCTION}

Speaking is one of the most difficult aspects for students to master in English [1]. It was also experienced by the students that the researcher had observed. The students were shy when the teacher asked them to speak English in front of the class. They were afraid of making mistake because of the lack of vocabulary mastery or grammar. Also, they did not have motivation from themselves to speak English. To solve that problem, the teacher should not take up class time by lecturing the materials only, instead she should spend the time to provide students' activities to speak as much as possible. In other words, teaching process should be student - centred approach. Mutmainna [2] states that in English classroom, one of the latest approaches of teaching and learning English is by integrating technology in the classroom environment. The teacher should use interesting media to support students' learning process. Media are all aids which may be used by teachers and students to attain certain educational objectives. There are various modern media that can be used to support learning process. For example, camera, internet, electronic dictionary, etc.

Vlog is a new trend in blogging which is defined as a blog that use video as its main source. Current video blog is essentially text blogs with externally linked videos for each entry [3]. Vlog is viral among teenagers and it is interesting to be used as a media in learning speaking. By using vlog as media in teaching speaking, it means that the researcher also support the governments' program about 21st Century Education. Researcher suggest that there are nine principles for teaching 21 st century skills, including make it relevant, teach through the disciplines, simultaneously develop lower and higher order thinking skills, encourage transfer of learning, teach students to learn to learn, address misunderstandings directly, teamwork is an outcome and promotes learning, exploit technology to support learning, and foster students' creativity [4]. Thus, this research explore the implementation of one of nine principles for teaching 21 st century education in which modern technology can support the learning process and increase student's creativity.

Furthermore, in the previous studies, there are some researchers who have conducted related investigations. First, Maulidah [5] conducted a research on titled "Vlog: The Mean to Improve Students' Speaking Ability". The result of this study showed that vlog significantly improved students' speaking ability. This research focused on the term of vlogging and tools, vlogging stages, and the significance of it in improving students' ability. However, the researcher limits her discussion on explaining how to make a video blog that can improve on student's speaking skill. The second study, the researcher such as Maldin and Rezeki [6] conducted a research on titled "Stepping Up English Speaking Proficiency of Hospitals Students through Video blogs (Vlogs)". The research was a qualitative study. The data collected from case analysis on strategies implemented by researcher to integrate vlog in teaching and learning process. The aim of the research is to know the correlation between Vlog (video production) with instructional strategy or task based. The result of this study is vlogging is a part of instructional strategies which can be beneficial for ESP learning to create a project that relates with studying major and the questionnaire item stated 
that vlog make the respondents to enjoy learning English. Thus, it can be concluded that vlog is suitable to be implemented in ESP classroom as it might share a positive attitude for students' learning development and possibly improve students' problem solving and collaborative skill in a fun learning atmosphere. The last study, a qualitative research on titled "Students' Perceptions on the Use of English Vlog (Video Blog) to Enhance Speaking Skill" by Maldin and Rezeki [6]. The samples were five students of English Education Department of Universitas Islam Indonesia who learnt listening and speaking subject. The purposes of this research were: 1) to know how students' perception on the use of English Vlog to enhance speaking skill, and 2) to study about what student's strategy in using English Vlog to enhance speaking skill. The method of the research concerned to the students' perception in the use of English Vlog and students' strategy to use it while the data came from the students' interview, observation, and document. The result showed that students' perceptions on the use of English Vlog to enhance speaking skill are good through various strategies. Furthermore, students have good English skills by using English Vlog as the media to learn English.

Therefore, this research focuses on students' speaking skill after given vlog as a media in teaching speaking and the researcher is intended to give a meaningful contribution for teaching and learning process of speaking through using video blog.

\section{MethodS}

The design of this current study was quasi-experimental research design, specifically pretest-posttest control group design. It is kind of experimental designs that include random assignment, but the subjects cannot be randomly assigned.

This research was conducted in SMKS PGRI Pakisaji. The population of this research was ten grade students in academic year of 2018/2019. It was a class where the researcher did an observation when she was conducting her teaching practice at the school. There are two classes and two majors of ten grade and the total of the students are 36 students.

The subject of this research was divided into two groups; control and experimental group. The first group was experimental group who were taught using video blog (vlog) and the second group as a control group who were taught using video recording. The two groups got the same materials but with the different strategy of teaching. The control group got different treatment because it was the controller to recognize the different effect that was generated in the experimental group.

Therefore, to get the relevant data, the researcher used a speaking test as the instrument of the research. Instrument is the general term that researcher uses for a measurement device. There were two speaking tests that were implemented: pre-test and post-test. Pre-test is a test that the researcher gave to the experimental and control class before giving a treatment in order to measure and identify the students' level of speaking skills before the treatment; vlog and video recording. Post-test is a test that the researcher gave to experimental and control class after being given the treatment. The post-test is used to measure the effectiveness of the treatment. The purpose of post-test is to find out the differences between both of classes after given the treatment. The students took one of the tourism place pictures provided and presented it in front of the class.

In order to know how far the instrument measured the data and how consistent the test that measured, the validity and reliability were needed. Validity is an instrument which is used to check whether the instrument is valid and suitable or not to be applied on this research. There are three kinds of validity; construct validity, concurrent validity and content validity. In this research, the researcher used content validity because this research was held in formal education institution. Thus, the test as the main instrument has developed based on the syllabus that matched to the curriculum in SMKS PGRI Pakisaji 2018/2019. While reliability of measuring instrument is the degree of consistency with which it measures whatever it is measuring. The researcher evaluated the students' speaking test with a partner (inter-rater). Inter-rater was used to decrease subjectivity. The inter-rater of this research was the English teacher in SMKS PGRI Pakisaji.

In this research, the researcher computed the $t$-value by using independent sample $t$-test in SPSS 22.0 for windows in order to answer the problem of this study by comparing the result of post-test from both of classes. The estimation is if the value is less than 0.05 it means $\mathrm{Ha}$ is accepted. On the other hand, if the value is more than 0.05 it means that the Ho is accepted.

\section{FINDINGS}

The reliability of the test was found based on the result of the pre-test and the post test that were computed by using Cohen's Kappa on SPSS 22.0 for windows. According to Landis \& Koch [7] the Coefficient Index Kappa describe as follows:

TABLE I. THE COEFFICIENT INDEX KAPPA

\begin{tabular}{|l|l|}
\hline \multicolumn{1}{|c|}{ Kappa } & \multicolumn{1}{c|}{ Quality } \\
\hline $0.80-1.00$ & Perfect agreement \\
\hline $0.60-0.80$ & Substantial agreement \\
\hline $0.40-0.60$ & Moderate agreement \\
\hline $0.20-0.40$ & Fair agreement \\
\hline $0.00-0.20$ & Slight agreement \\
\hline
\end{tabular}

The researcher collaborated with English teacher at SMKS PGRI Pakisaji to give a students' speaking score. The pre-test and post test score was used to measure the reliability using Cohen's Kappa.

The pre-test value of coefficient Kappa in experimental class was 0.224 . According to Table 1 , it means that any fair 
agreement between rater 1 and rater 2 towards students speaking score, while the pre-test value of coefficient Kappa in control class was 0.127 . It means that any slight agreement between inter-rater 1 and inter-rater 2 towards students' speaking score.

Furthermore, the post-test value of coefficient Kappa in experimental class was 0.638 . According to Table 1 , it means that any substantial agreement between rater 1 and rater 2 towards students speaking score. In the other hand the post-test value of coefficient Kappa in control class was 0.127. It means that any slight agreement between inter-rater 1 and inter-rater 2 towards students speaking score.

To measure the normality of the test, this study used one sample Shapiro-Wilk by using SPSS version 22.0 for windows. The interpretation of the result in this test is when the significant value is $>0.05$, it means that the data is normally distributed. In contrast, if the result of the score is $<0.05$ it means that the data is not distributed normally. The result of normality of pre-test can be seen on the column of ShapiroWilk. The sig. score of X-AKL as the experimental group was 0.069 and the significance of X-OTKP as the control group was 0.106 . It can be concluded that both of classes had normal distribution because the score of significance was $>0.05$. Meanwhile, the result of normality of post-test can be seen on the column of Shapiro-Wilk. The sig. score of X-AKL as the experimental group was 0.173 and the significance of X-OTKP as the control group was 0.098 . The score of significance was > 0.05 . It can be concluded that both of classes had the normal distribution.

To examine the homogeneity of the test the researcher used Lavene test use SPSS 22.0 for windows. If the significant value of Lavene test is $>0.05$, it means the data is homogeneous. Then, if the significant of the study is $<0.05$ it means that the data is heterogeneous. Homogeneity test is a test which is used to know the similarity of research sample characterization from both of classes. The significance score of homogeneity of pretest was 2.448. It means that the samples is homogeneous because the significance $>0.05$. Indeed, the experimental group and the control group had the same level of speaking skill. Meanwhile, the significance score of homogeneity of post-test was 0.273 . It means that the samples is homogeneous because the significance $>0.05$. Indeed, the experimental group and the control group had the same level of speaking skill.

In addition, the result of the significant (2-tail) value was 0.000 , which was less than 0.05 . It means that the alternative hypothesis (Ha) was accepted, and the null hypothesis (H0) was rejected. The mean score of both classes also had differences. The students' mean score in experimental class was 51.37. Meanwhile the mean score of students in control class was 43.41. It means that the students who were taught using vlog had greater score than students who were taught using video recording.

\section{DISCUSSION}

The researcher decided to extend the research by identifying the effectiveness of Video Blog (Vlog) on students' speaking skill. This study used quasi-experimental research designed that had aim to find out whether Video Blog (Vlog) has significant effect or not to increase the students' speaking skill on descriptive text at ten grades of SMKS PGRI Pakisaji. Related to the result of this study, the experimental group had significant effect on students' speaking skill on descriptive text by using Vlog.

On the basis of the findings of the study, vlog is a new media in teaching speaking that can help students to improve their speaking skill and the students' motivation in learning speaking English. By giving an assignment to make a vlog, the teacher gave an opportunity for the students to try to make video in describing tourism place that can help them practice their confidence in speaking because they were free to express their ideas and their feeling.

The implementation of Vlog also makes students creative. Moreover, the students make script to help them before creating the vlog. Writing script or drafting process also helps the students to increase their vocabulary, because they have found some new vocabulary about tourism place. By writing a script, the students also can check the grammar before speech in front of the camera.

The implementation of vlog on students' speaking about describing a tourism place gives a new experience for the students, because the teacher rarely implements this material into speaking. The teacher only focuses on writing process, but this study gives new experience in descriptive text about tourism place that focuses on speaking without ignoring the generic structure of description text. The students create the draft according to the generic structure of description text and explain it by speaking in front of the camera.

In general, the result of this study confirms the result of the previous study that was conducted by Khoiriyah and Safitri [8]. It was a qualitative study where the data were obtained from case analysis on strategies implemented by researcher to integrate vlog in teaching and learning process. The aim of the study is to know the correlation between Vlog (video production) with instructional strategy or task based. The result of this study is vlogging is a part of instructional strategies which can be beneficial for ESP learning to create a project that relates with studying major and the questionnaire result stated that vlog makes the respondents enjoy learning English.

The result of present study also confirms the result of the previous study that was conducted by Landis and Koch [9]. It was a qualitative research study. The samples were five students of English Education Department of Universitas Islam Indonesia who learnt listening and speaking subject. The purposes of this research are: 1) to know how students' perception on the use of English Vlog to enhance speaking skill, and 2) to study about what student's strategy in using English Vlog to enhance speaking skill. The method of the 
research concerned to the students' perception in the use of English Vlog and students' strategy to use it while the data came from the students' interview, observation, and document. The result showed that students' perceptions on the use of English Vlog to enhance speaking skill were good through various strategies. Furthermore, students have good English skills by using English Vlog as the media to learn English.

Teaching speaking by using Vlog is not easy, because the students only know the meaning of Vlog, but they never make it. During teaching vlog, the researcher explained first about what vlog is and how to create it also helped them in editing. In the first vlog, the students said that creating a vlog is difficult, because they should make a script and then try to improve it during creating a video. The students should be confidence and they should finish editing the video. On the second vlog, they were enjoying the process. In conclusion, using vlog as the media in teaching speaking can improve the students' speaking skill.

Vlog is more effective than video recording because, it is a new trend in blogging and very famous on the teenagers nowadays. The students were excited when the researcher implemented vlog as a new media in teaching speaking. It is supported by the students' questions when the researcher explained about vlog. They asked how vlog can being a media in speaking, how to create a vlog in descriptive text. Thus, the students were excited to create a vlog. In vlogging process, the researcher also gave the students opportunity to come to tourism place in Malang. So, they do not only do their assignment but also refresh their mind. In other hand, after finishing the vlog, they should upload into application (Edmodo) and get the feedback from the teacher and also from the other friends. By uploading the vlog into Edmodo, every student can watch their friends' vlog and it can be the motivation for the students to make an interesting vlog than their friends. Therefore, it also gives information that learning process is not only in the classroom but also can utilize the mobile phone as the media in learning process. Meanwhile, video recording is a common media in teaching speaking. So, the students do not give an excited respond when the researcher explain about it. Actually, in process creating a video recording same as creating a vlog, but in video recording the students give the original video without editing and without uploading into an application or Web. The students submit their product into the teacher, so they get the feedback only from the teacher.

\section{CONCLUSION}

The researcher used pretest-posttest control group research design. The sample of this research was the ten grade students' of SMKS PGRI Pakisaji. The statistical analysis showed that the significant $(2$-tail) value was $0.000<0.05$. It means that the alternative hypothesis (Ha) was accepted, and the null hypothesis (H0) was rejected. The mean score of both classes also had differences. The students' mean score in experimental class was 51.37. Meanwhile the mean score of students in control class was 43.41. It means that the students who were taught using vlog had greater score than students who were taught using video recording.

Based on the finding, it could be concluded that there was a significant difference score on students' speaking between students in experimental class who were taught using video blog and control class who were taught using video recording.

\section{REFERENCES}

[1] K. Sara, "Teaching english at Damascus University medical school," East. Mediterr. Heal. J., vol. 15, no. 3, pp. 653-664, 2009.

[2] M. Mutmainna, "Implementing Blogs As a Learning Tool in Asian Efl/Esl Learning Context," BRAC Univ. J., vol. 1, no. 1, pp. 27-35, 2016.

[3] G.C. Davison, "Behaviour Therapy," British Journal of Psychiatry, vol. 112, no. 483, pp. 211-211, 1966

[4] A. R. Saavedra, 21.Century Skills, pp. 1-35, 2012.

[5] I. Maulidah, "Vlog: the Mean to Improve Students' Speaking Ability," In International Conference on English Language Teaching (ICONELT 2017) pp. 12-15, 2017.

[6] S.A. Maldin and S.R.I. Rezeki, "Stepping Up the English Speaking Proficiency of Hospitality Students through Video Blogs (Vlogs)," International Conference on Languages and Arts, vol. 148, pp. 58-63, 2018

[7] J.R. Landis and G.G. Koch, "The measurement of observer agreement for categorical data," Biometrics, pp. 159-174, 1977.

[8] I. Khoiriyah and N.S. Safitri, "Students ' perceptions on the use of English Vlog (video blog) to enhance speaking skill," Asian Acad. Soc. Int. Conf. Proceeding, pp. 240-247, 2017.

[9] J.R. Landis and G. G. Koch, "Kappa and Observer Agreement," Biometrics, vol. 33, no. 1, pp. 159-174, 1977. 